E3S Web of Conferences 1, 13002 (2013)

DOI: $10.1051 / \mathrm{e} 3$ sconf/20130113002

(c) Owned by the authors, published by EDP Sciences, 2013

\title{
Uptake of Cadmium by Lemna minor, a (hyper?-) accumulator plant involved in phytoremediation applications
}

\author{
D. Bianconi ${ }^{1}$, F. Pietrini ${ }^{2}$, A. Massacci ${ }^{3}$ and M. A. Iannelli ${ }^{4}$
}

${ }^{1}$ University of Tuscia, Department for Innovation in Biological, Agro-food and Forest systems (DIBAF), Via San Camillo de Lellis, 01100 Viterbo, ITALY, daniele.bianconi@ibaf.cnr.it

${ }^{2}$ Institute of Agro-Environmental and Forest Biology (IBAF)- National Research Council (CNR) Via Salaria km 29.300, 00015 Monterotondo scalo. Rome ITALY, fabrizio.pietrini@ibaf.cnr.it

${ }^{3}$ Institute for Water Research (IRSA), National Research Council (CNR), Via Salaria Km 29,300, 00015 Monterotondo

Scalo (Rome) ITALY, massacci@irsa.cnr.it

${ }^{4}$ Institute of Agricultural Biology and Biotechnology (IBBA) - National Research Council of Italy (CNR), Via Salaria km 29.300, 00015 Monterotondo Scalo. Rome ITALY, iannelli@ibba.cnr.it

\begin{abstract}
Metal pollution in waters and soils is a major environmental and human health problem. Cadmium $\left(\mathrm{Cd}^{2+}\right)$ is a heavy metal displaying toxic effects in plants. In this work we studied the potentiality of Lemna minor, a monocotyledonous aquatic macrophyte, to phytoremediate cadmium-polluted waters. The plants were exposed to different cadmium concentrations $0,13,22$ and $46 \mu \mathrm{M} \mathrm{CdSO}_{4}$ for a period of 24,48 and 72 hours. Relative growth rates (RGR), bioconcentration factor $(\mathrm{BCF})$, tolerance index $\left(\mathrm{T}_{i}\right)$, cadmium uptake in whole plant and maximum efficiency of PSII (Fv/Fm) were measured under controlled climate conditions. RGR, $\mathrm{T}_{i}$ and $\mathrm{Fv} / \mathrm{Fm}$ declined with increasing exposure time and cadmium concentrations, while the $\mathrm{BCF}$ and cadmium uptake showed an opposite behavior. Data analysis of RGR, BCF, Ti and $\mathrm{F}_{\mathrm{V}} / \mathrm{F}_{\mathrm{M}}$ indicates that $L$. minor maintains a good capacity of growth, metal bioconcentration, tolerance and efficiency of PSII up to $48 \mathrm{~h}$ in plants exposed to 13 and $22 \mu \mathrm{M} \mathrm{CdSO}_{4}$. Our results exhibited that L. minor is a good cadmium accumulator and is able to remediate Cd-polluted waters, especially at low Cd concentrations.
\end{abstract}

Key words: Lemna minor, cadmium (Cd), phytoremediation, chlorophyll a fluorescence.

\section{Introduction}

Heavy metal pollution of soils and waters is a very serious environmental problem with potentially harmful consequences for agriculture and human health. The modern agricultural practices and the industrial activities have polluted soils and waters with great amounts of heavy metals (Rascio and Navari-Izzo 2010). Cadmium (Cd) was selected in this study since this metal ion, is toxic to living organisms and is a widespread, naturally occurring, element that is present in soils, rocks, waters, plants and animals. Cd is included among the top twenty worst polluting chemicals (Harris et al. 2011) Cd is harmful because it can replace some essential elements that play key roles in active sites of enzymes, and also because of its high affinity for sulfhydryl groups (Pietrini et al. 2005). Furthermore, European Directive in the field of water policy has established that cadmium with mercury, nickel and lead are priority hazardous substances in aquatic environment and has introduced severe measures to prevent or limit inputs of these pollutants into groundwater (Directive 2000/60/EC).
There is a considerable interest in developing cost effective and environmentally friendly technologies for the remediation of wastewater polluted with toxic trace elements. Cd extraction from water can be carried out in situ, at rates much higher than in soils, and is one of the effective and promising phytoremediation technologies (Prasad et al. 2010). The ideal plants for phytoextraction should possess the ability to tolerate and accumulate high levels of heavy metals in their harvestable parts, while producing high biomass. Many species of macrophytes are used for phytoremediation research for wastewater treatment (Khellaf and Zerdaoui 2009). One of the most commonly used aquatic plant is Lemna minor belonged to the family of Lemnaceae. In particular, Lemna minor is a free-floating, aquatic perennial plant that forms a rapidly-expanding mat of foliage (to $1 / 4$ " tall) on water surface, able to remove and accumulate large amounts of cadmium, principally through the fronds (Zayed et al. 1998). Thus, this study was carried out to evaluate the ability of Lemna minor to tolerate, remove and bioconcentrate cadmium in a short-term experiment. 


\section{Materials and Methods}

The experiments reported in this paper were conducted on a geographically isolated clone of Lemna minor. Before metal treatment, plants (30 fronds corresponding to a leaf surface of about $3 \mathrm{~cm}^{2}$ ) were acclimatized in plates (diameter $3 \mathrm{~cm}$ ) for 20 days under controlled climate conditions $\left(23 / 19^{\circ} \mathrm{C}\right.$ and $14-\mathrm{h}$ photoperiod, photon flux density of $\left.350 \mu \mathrm{mol} \mathrm{m} \mathrm{m}^{-1}\right)$. The plants were then treated with Hoagland mineral solution (Forni et al., 2001) containing $0,13,22$ and $46 \mu \mathrm{M} \mathrm{CdSO}_{4}$ under the aforementioned conditions for periods of 24,48 and $72 \mathrm{~h}$. In response to metal exposure, relative growth rate (RGR), bioconcentration factor (BCF), tolerant index $(\mathrm{T} i)$, cadmium uptake in whole plant, and maximum efficiency of photosystem II (Fv/Fm) were analysed.

L. minor relative growth rates were calculated according to Hunt's equation:

$$
\mathrm{R}=\ln \mathrm{W}_{2}-\ln \mathrm{W}_{1} / \mathrm{T}_{2}-\mathrm{T}_{1}
$$

where $\mathrm{R}$ is the relative growth rate $\left(\mathrm{g} \mathrm{g}^{-1}\right.$ day $\left.^{-1}\right)$, and $\mathrm{W}_{1}$, $\mathrm{T}_{1}$ and $\mathrm{W}_{2}, \mathrm{~T}_{2}$ are the initial and final dry weights and times for each day treatment, respectively (Hunt 1978).

The bioconcentration factor (BCF) was calculated as follows (Rahmani and Stenberg 1999):

$$
\begin{gathered}
\mathrm{BCF}=\mathrm{Cd} \text { in plant biomass }\left(\mathrm{mg} \mathrm{kg}^{-1}\right) / \\
\mathrm{Cd} \text { in solution }\left(\mathrm{mg} \mathrm{l}^{-1}\right)
\end{gathered}
$$

Tolerance index (Ti) was calculated as follows (Lux et al. 2004):

$$
\begin{aligned}
& \mathrm{T} i=\text { dry weight of plants grown in Cd solution / } \\
& \text { dry weight of plants grown in control solution }
\end{aligned}
$$

At the end of each day of treatment, plants were harvested and oven-dried at $105^{\circ} \mathrm{C}$ for $48 \mathrm{~h}$. Each sample was then digested with pure $\mathrm{HNO}_{3}: \mathrm{H}_{2} \mathrm{O}(1: 1)$ for $72 \mathrm{~h}$. After digestion, the volume of each sample was adjusted to $25 \mathrm{ml}$ using double deionized water. Determinations of $\mathrm{Cd}$ concentration in plant were carried out by atomic absorption spectrometry (AAnalyst-300, HGA-800, Perkin Elmer)

Maximum efficiency of photosystem II (PSII) was characterized by variable to maximum chlorophyll $a$ fluorescence ratio $\left(\mathrm{F}_{\mathrm{V}} / \mathrm{F}_{\mathrm{M}}\right)$ measured by means of chlorophyll fluorescence imaging (FluorCam MF700, PSI, Brno, Czech Republic). Plants were first darkadapted for $20 \mathrm{~min}$. During the measurement, the plants were exposed first to low irradiation $\left(5 \mu \mathrm{mol} \mathrm{m} \mathrm{m}^{-2}\right)$ for the determination of basal chlorophyll fluorescence $\left(\mathrm{F}_{0}\right)$. Then a saturating light flash $\left(1500 \mu \mathrm{mol} \mathrm{m} \mathrm{m}^{-2} \mathrm{~s}^{-1}\right)$ was applied to determine maximum fluorescence $\left(\mathrm{F}_{\mathrm{M}}\right)$. The maximum efficiency of PSII $\left(\mathrm{F}_{\mathrm{V}} / \mathrm{F}_{\mathrm{M}}\right)$ value was calculated according to the equation :

$$
\mathrm{F}_{\mathrm{V}} / \mathrm{F}_{\mathrm{M}}=\left(\mathrm{F}_{\mathrm{M}}-\mathrm{F}_{0}\right) / \mathrm{F}_{\mathrm{M}}
$$

All data were subjected to ANOVA and LSD test was used to separate the means.

\section{Results and Discussion}

Relative growth rates (RGR) of L. minor declined with increasing exposure time and $\mathrm{Cd}$ concentrations (Fig.1). The highest RGR reduction was found in plants exposed to $46 \mu \mathrm{M} \mathrm{CdSO}_{4}$ while no significant differences were observed in the other two concentrations. Our results are in line with Uysal and Taner (2007) that found a growth reduction in L. minor during the exposure to similar $\mathrm{Cd}$ concentrations for 7 days.

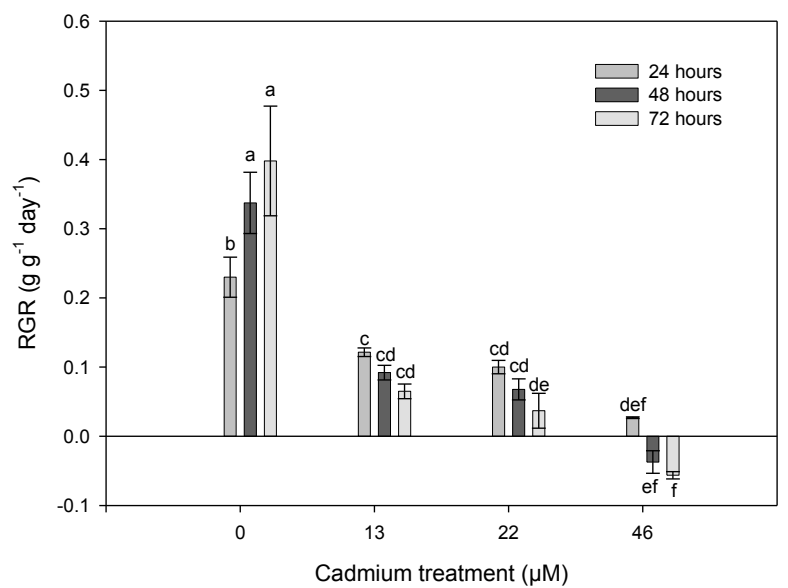

Fig. 1. Relative growth rate of Lemna minor treated with 0 (Control), 13, 22 and $46 \mu \mathrm{M} \mathrm{CdSO}_{4}$ during the 3 days of experiment. Data are given as means of six replicates \pm standard error (SE). Bars with the same letter were not significantly different $(\mathrm{P}<0.05$, ANOVA; LSD mean comparisons test).

To evaluate the ability of plants to concentrate $\mathrm{Cd}$ from the external solutions in their tissues, the bioconcentration factor (BCF) was calculated. As reported in table $1, \mathrm{BCF}$ of $L$. minor showed an increase in all tested $\mathrm{Cd}$ treatments and in response to time exposure. In particular, all $\mathrm{Cd}$ treatments showed the highest values of BCF at the end of the experiment (72h). However the highest $\mathrm{BCF}$ values were measured in plants exposed to $13 \mu \mathrm{M} \mathrm{CdSO}$. Our results confirmed the indication suggested by Zayed et al. (1998) for whom a plant is considered a good accumulator when reaches a $\mathrm{BCF}$ over 1000 . In fact, we found values of BCF very close to 1000 after $48 \mathrm{~h}$ of treatment and upper to 1000 after $72 \mathrm{~h}$ in plants exposed to 13 and $22 \mu \mathrm{M} \mathrm{CdSO}_{4}$.

Table 1. Bioconcentration factor (BCF), tolerance index ( $\mathrm{T} i$ ) and cadmium uptake measured during the 3 days of experiment in fronds of Lemna minor treated with 13, 22 and $46 \mu \mathrm{M} \mathrm{CdSO}_{4}$. Values are means of six replicates \pm standard error (SE). Within columns, values with the same letter were not significantly different $(\mathrm{P}<0.05$, ANOVA; LSD mean comparisons test).

\begin{tabular}{ccrcc}
\hline $\begin{array}{c}\text { Conc } \\
(\mu \mathrm{M})\end{array}$ & $\begin{array}{c}\text { Time } \\
(\mathrm{h})\end{array}$ & BCF & $\mathrm{T} i$ & $\begin{array}{c}\text { Cd uptake } \\
(\mu \mathrm{g} / \text { plate })\end{array}$ \\
\hline $\mathbf{1 3}$ & $\mathbf{2 4}$ & $\mathbf{4 7 6} \pm 21 \mathrm{f}$ & $\mathbf{0 . 7 8} \pm 0.03 \mathrm{a}$ & $\mathbf{2 . 1 2} \pm 0.17 \mathrm{f}$ \\
& $\mathbf{4 8}$ & $\mathbf{8 7 5} \pm 26 \mathrm{c}$ & $\mathbf{0 . 6 1} \pm 0.02 \mathrm{bc}$ & $\mathbf{4 . 4 3} \pm 0.18 \mathrm{e}$ \\
& $\mathbf{7 2}$ & $\mathbf{1 2 7 5} \pm 32 \mathrm{a}$ & $\mathbf{0 . 4 3} \pm 0.02 \mathrm{~d}$ & $\mathbf{6 . 7 5} \pm 0.18 \mathrm{c}$ \\
\hline $\mathbf{2 2}$ & $\mathbf{2 4}$ & $\mathbf{3 6 7} \pm 6 \mathrm{~g}$ & $\mathbf{0 . 8 2} \pm 0.02 \mathrm{a}$ & $\mathbf{2 . 8 3} \pm 0.21 \mathrm{f}$ \\
& $\mathbf{4 8}$ & $\mathbf{7 2 1} \pm 22 \mathrm{~d}$ & $\mathbf{0 . 6 3} \pm 0.02 \mathrm{~b}$ & $\mathbf{6 . 2 0} \pm 0.42 \mathrm{~cd}$ \\
& $\mathbf{7 2}$ & $\mathbf{1 0 7 5} \pm 38 \mathrm{~b}$ & $\mathbf{0 . 4 4} \pm 0.02 \mathrm{~d}$ & $\mathbf{9 . 5 7} \pm 0.64 \mathrm{~b}$ \\
\hline $\mathbf{4 6}$ & $\mathbf{2 4}$ & $\mathbf{3 5 4} \pm 5 \mathrm{~g}$ & $\mathbf{0 . 8 0} \pm 0.01 \mathrm{a}$ & $\mathbf{5 . 2 5} \pm 0.47 \mathrm{de}$ \\
& $\mathbf{4 8}$ & $\mathbf{5 9 9} \pm 4 \mathrm{e}$ & $\mathbf{0 . 5 5} \pm 0.01 \mathrm{c}$ & $\mathbf{8 . 7 6} \pm 0.42 \mathrm{~b}$ \\
& $\mathbf{7 2}$ & $\mathbf{8 4 5} \pm 3 \mathrm{c}$ & $\mathbf{0 . 3 5} \pm 0.01 \mathrm{e}$ & $\mathbf{1 2 . 2 8} \pm 0.38 \mathrm{a}$ \\
\hline
\end{tabular}


To assess the capability of plants to grow in the presence of a given concentration of metal, the tolerance index (Ti) was calculated. As reported in table 1, Ti of $L$. minor showed a decrease in all tested Cd treatments and in response to time exposure. Plants with Ti higher than 0.6 are considered tolerant (Lux et al. 2004). Our results showed a good tolerance to $\mathrm{Cd}$ in plants exposed to 13 and $22 \mu \mathrm{M} \mathrm{CdSO}_{4}$ after $48 \mathrm{~h}$, since we found values of $\mathrm{T} i$ equal and/or higher than 0.6 .

These results are well correlated with the Cd uptake detected in L. minor plants and reported in table 1. Plants accumulated high amounts of $\mathrm{Cd}$ in a concentration- and time-dependent manner. The highest $\mathrm{Cd}$ uptake was observed in plants exposed to $46 \mu \mathrm{M} \mathrm{CdSO}_{4}$ after $72 \mathrm{~h}$. The lower Cd content was measured in plants exposed to $13 \mu \mathrm{M}$ and $22 \mu \mathrm{M} \mathrm{CdSO}_{4}$ after $72 \mathrm{~h}, 50 \%$ and $25 \%$ lower, respectively, compared to that one measured in plants grown at $46 \mu \mathrm{M} \mathrm{CdSO}_{4}$ after $72 \mathrm{~h}$.

To analyse the effect of cadmium treatments at physiological level, the maximum efficiency of PS II $\left(\mathrm{F}_{\mathrm{V}} / \mathrm{F}_{\mathrm{M}}\right)$ was measured. The $\mathrm{F}_{\mathrm{V}} / \mathrm{F}_{\mathrm{M}}$ values showed reduction in all tested $\mathrm{Cd}$ treatments and in response to time exposure (Fig.2). The lowest value of $\mathrm{F}_{\mathrm{V}} / \mathrm{F}_{\mathrm{M}}$ was observed after 72 hours in plants exposed to $46 \mu \mathrm{M}$ $\mathrm{CdSO}_{4}$. The increased amount of $\mathrm{Cd}$ uptake affected the efficiency of photosystem II with a corresponding significative decrease of $\mathrm{F}_{\mathrm{V}} / \mathrm{F}_{\mathrm{M}}$. Our results agree with Zhang et al. (2007) that found a reduction of $F_{V} / F_{M}$ and other fluorescence parameters in L. minor during the exposure to similar $\mathrm{Cd}$ concentrations for 2 days.

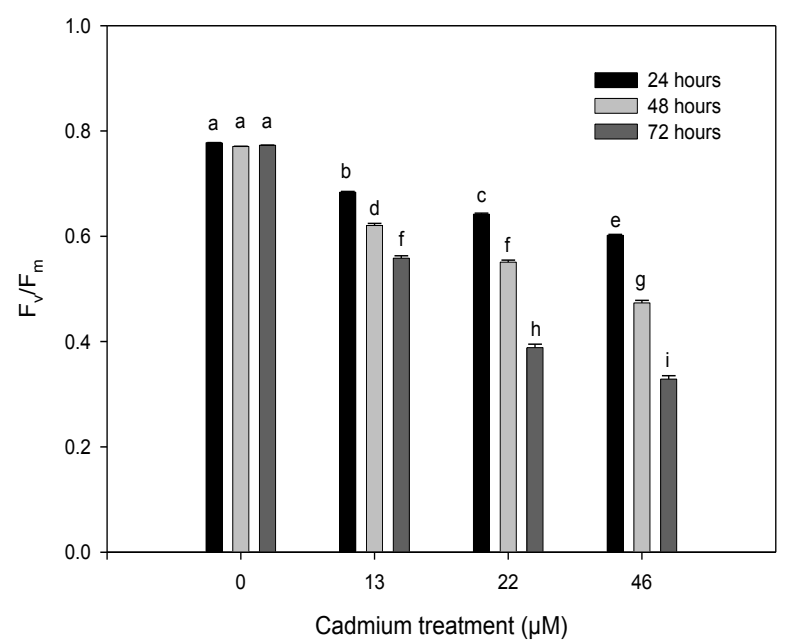

Fig. 2. Effect of cadmium on maximum efficiency of PSII $\left(\mathrm{F}_{\mathrm{v}} / \mathrm{F}_{\mathrm{m}}\right)$ in fronds of Lemna minor treated with 0 (Control), 13, 22 and $46 \mu \mathrm{M} \mathrm{CdSO}_{4}$ during the 3 days of experiment. Data are given as means of six replicates \pm standard error (SE). Bars with the same letter were not significantly different $(\mathrm{P}<0.05$, ANOVA; LSD mean comparisons test).

\section{Conclusions}

In this study, we investigated the toxic effects of $\mathrm{Cd}$ and its bioaccumulation on L. minor. Lemna showed to be a plant with great capability of $\mathrm{Cd}$ absorption and accumulation in the fronds, with a potential use in phytoremediation field.
The combined data analysis of RGR, BCF, T $i$ and $\mathrm{F}_{\mathrm{V}} / \mathrm{F}_{\mathrm{M}}$ indicates that $L$. minor showed a good capacity of growth, metal bioconcentration, tolerance and photosynthetic efficiency up to $48 \mathrm{~h}$ in plants exposed to 13 and $22 \mu \mathrm{M} \mathrm{CdSO}_{4}$. In particular, under the aforementioned conditions, Lemna was able to accumulate up to $1800 \mathrm{mg} / \mathrm{kg}$ (data not shown) on dry matter basis higher than $0.01 \%$ defined as threshold $\mathrm{Cd}$ concentration for hyperaccumulator plants (Baker and Brooks 1989). Furthermore, in front of such high accumulation, Lemna showed a good protection of its photosynthetic apparatus as indicated by its $\mathrm{Fv} / \mathrm{Fm}$ maintenance, up to $46 \mu \mathrm{M}$ CdSO 4 after $24 \mathrm{~h}$.

According to obtained results, L. minor can be considered a good accumulator of Cd especially at low Cd concentrations. Infact, L. minor has potential for the remediation of Cd-polluted waters because of its high accumulation capacity, rapid growth rate and the ease of culture and harvest.

\section{References}

Baker AJM, Brooks RR. Terrestrial higher plants which hyperaccumulate metallic elements- a review of their distribution, ecology and phytochemistry. Biorecovery 1989; 1: 81-126.

Directive 2000/60/EC of the European Parliament and of the Council of 23 October 2000 establishing a framework for Community action in the field of water policy. OJ L 327, 2000, 1-73.

Forni C, Nicolai MA, D'Egidio MG. 'Potential of the small aquatic plants Azolla and Lemna for nitrogenous compounds removal from wastewater', in C. A. Trebbia (ed.), Water Pollution VI. Modeling, Measuring and Prediction, WIT Press, Southampton, Boston, U.S.A., 2001; pp. 315-324.

Harris J, McCartor A, Fuller R, Ericson B, Caravanos J, Hanrahan D, Keith J, Becker D. The Top Ten of the Toxic Twenty The World's Worst Toxic Pollution Problems Report. Blacksmith Institute and Green Cross Switzerland. Online at www.worstpolluted.org 2011, pp. 1-76.

Hunt R. Plant growth analysis. Studies in biology. London: Edward Arnold. 1978; p. 67.

Khellaf N, Zerdaoui M. Growth response of the duckweed Lemna minor to heavy metal pollution. Iran. J. Environ. Health. Sci. Eng. 2009; 6 (3): 161166.

Lux A, Šottníková A, Opatrná J, Greger M. Differences in structure of adventitious roots in Salix clones with contrasting characteristics of cadmium accumulation and sensitivity. Physiologia Plantarum 2004; 120: 537-545.

Pietrini F, Iannelli MA, Montanari R, Bianconi D, Massacci A. Cadmium interaction with thiols and photosynthesis in higher plants. In A. Hemantaranjan (Ed.), Advances in plant physiology Jodhpur, India: Scientific Publishers 2005; pp. 313326.

Rahmani GNH, Stenberg SPK. Bioremoval of lead from water using Lemna minor. Bioresource technology 1999; 70: 225-230.

Prasad MNV, Freitas H, Fraenzle S, Wuenschmann S, Markert B. Knowledge explosion in 
phytotechnologies for environmnetal solutions. Environmental Pollution 2010; 158: 18-23.

Rascio N, Navari-Izzo F. Heavy metal hyperaccumulating plants: How and why do they do it? And what makes them so interesting? Plant Science 2010; 180: 169-181.

Uysal Y, Taner F. The effect of cadmium ions on the growth rate of the freshwater macrophyte duckweed
Lemna minor. Ekoloji, 2007; 62: 9-15.

Zayed A, Gowthaman S, Terry N. Phytoaccumulation of trace elements by wetland plants: I. Duckweed. J Environ. Qual. 1998; 27: 715-721.

Zhang J, Chen J, Hu Y, Mo Y. Effects of cadmium stress on photosynthetic function of leaves of Lemna minor L. Journal of Agro-Environment Science 2007; 6: 2027-2032. 